\title{
Monopoly of State-Owned Enterprise of Social Justice
}

\author{
Rory Jeff Akyuwen \\ Faculty of Law, Pattimura University \\ Jln. Ir. M. Putuhena Kampus Poka, Ambon, 97233, Indonesia \\ Tel./Fax: +62-911-3825204, E-mail: rjakyuwen@gmail.com
}

\begin{abstract}
The role of the state through BUMN becomes so important when it is formulated in a provision as formulated in Article 33 Paragraph (2) of the 1945 Constitution of the State of the Republic of Indonesia, where the production branches which are important for the State and which affect the livelihood of the public must be controlled by Country. Here it indicates the authority of the State to participate in economic activities through the operation of production branches that can be categorized as important for the State and considered vital and strategic for the interest of the State.This is based on the reasons as formulated in the explanatory section of Article 33 of the 1945 Constitution of the State of the Republic of Indonesia, so that the benefits of the production branches do not fall into the hands of individuals, the State actively takes the role to cultivate it because the production branch is considered important and which control the livelihood of the people for the greatest prosperity of the people. State-Owned Enterprises is formed with the aim of contributing to the development of the national economy in general and the state's revenue in particular; The pursuit of profit; To hold general benefit in the form of providing goods and / or services of high quality and adequate for the fulfillment of the livelihood of the public; Pioneering business activities that have not yet been implemented by the private sector and cooperatives and actively providing guidance and assistance to weak economic entrepreneurs, cooperatives, and communities.SOEs are given the right to monopoly in the economic field which is considered to control the livelihood of many people.
\end{abstract}

Keywords: monopoly; social justice

\section{INTRODUCTION}

State monopoly through State-Owned Enterprises in the field of economy in Indonesia is the implementation of Article 33 of the 1945 Constitution of the State of the Republic of Indonesia where it is stated that the production branches which control the livelihood of the people are controlled by the state and are used as much as possible for the welfare of the people.

The first reason for the establishment of State-Owned Enterprises at the beginning of the Republic stands normative in order to fulfill the mandate of the Preamble of the 1945 Constitution of the State of the Republic of Indonesia 
which obliges the state to strive for the welfare of its people, as well as the elaboration of Article 33 paragraph (2) which states: And which affect the livelihood of the masses dominated by the state. Paragraph (3) of the same Article states: Earth and water and natural resources contained therein are controlled by the state and used for the greatest prosperity of the people. ${ }^{1}$

These two verses form the basis that the state directly controls all natural resources and needs to run various business activities as the company deserves to earn income for the welfare of the people. The second reason is practical, ie in the early days of independence there has not been a large private company, let alone a national scale. Indeed there are a number of large companies inherit the Dutch colonial government, but its ownership is still in the hands of the Dutch / foreign businessmen, and assets and mechanisms are usually already ravaged by the Japanese occupation government. It seems that this second reason is more pronounced because among the Fathers of the Nation there are different views about the

\footnotetext{
1 Faisal Basri. (2002). Perekonomian Indonesia Tantangan Dan Harapan Bagi Kebangkitan Indonesia. Jakarta: Erlangga. pg. 263
}

manifestation of Article 33 of the 1945 Constitution. $^{2}$

Soekarno considered Article 33 of the 1945 Constitution requires the state to directly control all or most of the fields of business that directly wrestle in the market as a driver of the economy. Mohammed Hatta who actually mastered the economic discipline did not agree and he insisted that the Article must be interpreted the state should only control the company whose fields really master the basic needs of society such as electricity and transportation vehicles. However, for practical reasons, that very few companies existed to drive the economy at that time, Mohammed Hatta further supported the establishment of state enterprises in many areas, including those that did not significantly affect the livelihood of the people, with all these notes being temporary. Once the national private sector begins to grow and mobilize the economy, the state must step back and concentrate on only a few areas that are truly vital and strategic.

At that time Mohammed Hatta had seen a fundamental internal contradiction in the body of state enterprises (later called SOEs), because the business motive (seeking profit as much as possible) and

\footnotetext{
${ }^{2}$ Ibid, pg. 264
} 
social motives (helping other financially disadvantageous parties) were so deeply united. ${ }^{3}$ That the achievement of political independence Full after the Dutch recognition of Indonesian sovereignty was not immediately overtaken by economic independence. Foreign companies, especially the Netherlands, continue to play a central role. Therefore, without paying much attention to the Round Table Conference agreement containing the Indonesian government's guarantees for the continuation of foreign companies, President Soekarno in 1950 ordered the nationalization of 12 Dutch and Dutch private railway companies, 11 in Java coordinated by Staat-spoor Wegen en Verenidge Spoorweg Bedriif And 1 in Sumatera (Deli Spoorweg Maatschappij) was taken over to Djawatan Kereta Api (DKA). Previously, nationalization was carried out on De Javasche Bank, a currency circulation bank, which became Bank Indonesia (Indonesian central bank). Other leaders agree with both nationalizations because it is impossible for an independent state to allow foreigners to regulate their currency and rail transport is absolutely necessary, even though by then most of its assets had been robbed of Japan. Thousands of kilometers of rail

\footnotetext{
${ }^{3}$ Ibid,pg. 363
}

rods, iron wooden bearings, locomotives and carriages were robbed by the Japanese, some were transferred to Burma in favor of Japan's mobilization to take over Burma as a foothold against India. Under compromised conditions, trains are still needed because only the longest available means of transportation are available. ${ }^{4}$

Mohammed Hatta also lobbied the Dutch that this was not a nationalist in the sense of deprivation of civil rights and this was proved by his willingness to negotiate compensation. Muhamad Hatta considered Indonesia, for a while still need the capital and experts of various Dutch companies, until Indonesia itself has more capital and educated personnel to manage various companies. The nationalization will only dissolve the empowerment plans of indigenous businessmen that Hatta believes can only take place gradually. In order to prevent further nationalization tendencies, Muhamad Hatta and a number of other economically-minded leaders strive to have a program of empowerment of national private entrepreneurs, among others, embodied in the form of Economic and Economic Empowerment Plan (RUP) and Benteng Program that can be implemented in the 1950s after the physical struggle Maintain independence

\footnotetext{
${ }^{4}$ Ibid. pg 364
} 
over. The Benteng program, launched in April 1950, was intended to encourage indigenous entrepreneurs to take traders of crops trade (the only source of foreign exchange at the time) when controlled by five Dutch trading companies. ${ }^{5}$

The limitation of managerial resources and the overly heated political atmosphere caused the plan of empowering the indigenous business to falter. Indigenous entrepreneurs (most of whom had political connections) were in collusion with Chinese entrepreneurs, giving rise to the phenomenon of the "AliBaba" businessman. Si Ali provides import licenses and political connections, while the Baba provides capital and organizes the company's operations. Benteng Program was declared failed and ended in 1955. Meanwhile, the presence of reliable indigenous businessmen who are expected never to appear. The government then implemented the "Indonesianization" program, which is an obligation for all foreign companies to recruit and place Indonesians in managerial positions, a program opposed by foreign firms. The obligation to educate Indonesian workers is considered very expensive and burdensome, let alone release key positions to the Indonesian workers. ${ }^{6}$

Impatient with these developments, coupled with the wrath of the Dutch intention to continue gripping West Irian, Bung Karno took a radical road opposed by Bung Hatta, which nationalized the Dutch company Which is considered important. In 1957 all the great Dutch plantations, all their research institutes (Proefstation voor Suikerriet, Proefstation voor Thee Proefstation voor Rubber, Proefstation voor Kina, etc.) were taken by experts and became what we now know as PTPs throughout the archipelago. KLM (Koninklije Luchtvaart Maatschappij) Indonesian branch following a number of airplanes as its main assets were nationalized to Garuda Indonesia Airways (now PT Garuda Indonesia). The KPN service carrier is also taken over. Furthermore, the Post, Telegraph en Telephone Dienst / PTT was nationalized to become the Postal Service, Telegraph and Telephone in 1961 converted into State Enterprise Post and Giro Telecommunications. In 1965, Postel PN was split into State Enterprise of Post and Giro (PN Pos \& Giro), and State Telecommunication Company which in

\footnotetext{
${ }^{6}$ Ibid,pg. 365
} 
1974 converted into a company and now becomes PT Telkom. ${ }^{7}$

Some other examples of nationalization are Nederlandshe Indische Levenverzekering en Lijvrente Maatschappij (NILLMIJ) converted into PN (then PT) Asuransi Jiwasraya; Postspaarbank diindonesiakan become the State Savings Bank (BTN); NV. Braat Machine Fabriek and Machine Fabriek \& Werf NV. Molen Fliet was changed to PT Barata Indonesia; NV. De Bromo, NV. De Industrie and NV. De Vulkan merged and changed into PT Boma Bisma Indra; NV. Droogdook Maatschappij was taken over to PT Dok dan Perkapalan Surabaya (DPS); NV. Chemicalien Handle Rathkamp \& Co.dinasionalisasi become PT Kimia Farma; And Artillerie Constructie Winkel (ACW) developed into PT Pindad.

The atmosphere of nationalization coupled with mass action led to chaos. In December 1958 Dutch managers and businessmen and their families (about 50,000 people) fled forever to the Netherlands, leaving their company's remains unceremonious, even though they later through the Dutch government demanded compensation. What Mohammed Hatta worried about was

\footnotetext{
${ }^{7}$ Ibid,pg. 365
}

actually happening. Muhammad Hatta's challenge is not related to the question of nationalism which became the reason for Soekarno's president to nationalize without proper planning.

Mohammed Hatta was opposed to nationalization because there was a guarantee of protection of foreign companies, especially the Dutch, in the $\mathrm{KMB}$, and more importantly, from the beginning Muhamad Hatta knew that most of the Dutch nationalized companies were actually only scraps of scrap (severely, the Netherlands then demanded the compensation of nationalization at a price Maximally, and worse, the ridiculous demands deemed deserted by Soekarno's presidency were instead obeyed and paid in installments by the New Order). Most of the Dutch nationalized companies have turned their valuable assets and business activities to other places so that economically not give positive contribution, even become the burden of the state. ${ }^{8}$

But the political situation made the voice of Mohammed Hatta increasingly inaudible. President Soekarno, through the Presidential Decree of 5 July 1959, carried out a third nationalization on an even greater scale. This time the nationalization

${ }^{8}$ Ibid,pg. 366 
of about 600 companies Foreign private (almost all Dutch). Nearly 300 of them are private plantation companies, more than one hundred mining companies, and the rest are trading companies, banking, insurance, communications and construction. All of them made state enterprises financed by the state budget and became an important contributing factor to the bankruptcy of the Indonesian economy in the mid-1960s. The fourth nationalization came about almost exclusively to foreign oil companies, especially Caltex, who controlled the oil fields of Riau, but this plan was blocked by the Army leadership under General Soeharto. Military personnel even provide direct escort for foreign companies.

It is not merely nationalization that is the cause of the national economic bankruptcy but rather the politicization and mismanagement of state enterprises that are so severe. Absence of experts and network / international business connections among various companies in Indonesia. This explains (in addition to domestic political developments) why Indonesia is so late in establishing its private sector compared to Singapore, Malaysia and the Philippines that keeps in touch with its former colonialists, including its various companies. Moreover, at that time state-owned companies were more of a political instinct than a healthy business unit. Bung Karno instead puts skilled managers at the helm and managers of state enterprises, but politicians and especially, military officers who became one of Bung Karno's ways of maintaining military stability and loyalty. Under these conditions, the state company began to be used as a cash cow. Business management is not working, and the accumulated profits (if any) are used for the business of pottery and some of course lost by the managers. ${ }^{9}$

The success of economic development in East Asian countries before the 1997-1998 crisis is often associated with the strong role of the Government. Unlike in Western countries that prioritize market mechanisms and occupy the government with minimal economic role, in East Asian countries governments and private sector interact in an institutional fabric that enables the attenuation of efficient and competitive business or industry growth. ${ }^{10}$

Before the crisis not a few liberal or neoclassical economists insisted that the success of East Asia remain fully explained by the theoretical framework they believe. Even among them there is a sneer by revealing the results of his

${ }^{9}$ Ibid.pg. 366

${ }^{10}$ Ibid.pg. 342 
research which indicates that the era of high growth in East Asia is almost over because of its topangan so far that cheap labor, natural resources, and capital cheap loans can no longer be continuously reliable. $^{11}$

Capitalism or Liberalism has indeed proved its worth in prospering society. However, from the point of view of physical development alone, communism is also able to do so although not as good as capitalism. The phenomenon of East Asian success also proves that Westernstyle capitalism is not the only system that guarantees economic success. The problem is more complicated if the benchmark of success is not solely the material aspect, but also the strengthening of human dignity and prestige. So far we say at least communism has failed to raise the dignity of the people. On the contrary, no one can guarantee that the system applied by the West and East Asia will continue to be able and successful to maintain the continuity of economic success, let alone at the same time strengthen the dignity of human beings.

From the experience of many countries we can draw the wisdom that as long as it is human engineering, nothing is lasting. Everything will and must change

\footnotetext{
11 Ibid. pg. 342
}

with the demands of time. The capitalism that is known today is much different from the ideal figure. For Indonesia the state monopoly through SOEs is not a problem. But what needs to be clarified what kind of monopoly is ideal because whatever is done by the state is only one final goal that is for the welfare of the people.

According to Sri Redjeki Hartono State intervention on economic activity is one of three important principles needed in order to develop the ideals of law viewed from the aspects of Trade and Economy Law in addition to the other two principles of the Balance Principles and the Principle of Public Oversight. ${ }^{12}$

In the view of Islam, the role of government is based on several arguments, namely:

a. Derivation of the concept of Caliphate,

b. The consequences of collective obligations (fard al-kifayah), and

c. The existence of market failure. ${ }^{13}$

In carrying out its role, the government has several policy instruments, among others: ${ }^{14}$

a. Production management and employment in public sector

12 Sri Redjeki Hartono. (2007). Hukum Ekonomi Indonesia. Malang: PT Bayumedia. pg. 12

13 Munrokhim Misanam Priyonggo Suseno M bhekti Hendrieanto. (2007). Ekonomi Islam. Jakarta: Rajagrafindo Persada. pg. 446

$14 \quad$ Ibid.pg. 463 
governments can play an effective role in managing public property (where people fail to manage yes). Setting production and employment in this sector can have a major impact in the economy as a whole.

b. Instruments related to promoting private sector activities, for example establishing regulations for the private sector, redistributing production factors and providing protection for vulnerable communities.

c. Pricing Policy, in which the state regulates prices by way of market intervention, pricing, or promoting price discrimination policies for specific groups of people, regions, or sectors in the public interest. Pricing policy is also necessary when the market can not compete perfectly so that the resulting price does not harm the community.

d. Fiscal policy, which is the management of the state budget adjusted to the principles of public finance.

e. Credit and monetary policy f. Investment in wealth and public sector surplus.

\section{ANALYSIS AND DISCUSSION State Functions}

In a mixed economic context, Friedmann describes four functions of the State, namely: ${ }^{15}$

a. Provider Provider capacity is implemented to meet the minimum standards required by the community in order to reduce the impact of a free market that could harm the community

b. Regulator In its function as a regulator, the State guarantees order as in the field of investment for the industry to grow and develop, regulation and restrictions on exports and imports in order to provide sufficient foreign exchange to support trade.

c. Direct intervention in the economy (Enterpreneur) This State's direct intervention is conducted through state-owned enterprises (BUMN) because there are business fields that are deemed to be protected because they relate to the livelihood of the community.

d. Supervisor (Umpire) This oversight function relates to various products of the rule of law to maintain order and justice while acting as law

\footnotetext{
Friedman, W. (1990). The State And Filosophi Of Law (Teori Dan Filsafat Hukum). Alih Bahasa Muhammad Arifin. Jakarta: CV. Rajawali. pg. 3
} 
enforcement. The state's bestuursdaad functions are carried out by the government with the authority to issue and revoke the licensing facilities (licenses), licenses (licenties), and concessions.

The regulatory function by the state (regelendaad) is done through the legislative authority by the DPR together with the government (executive). The management function (beheersdaad) is done through share holding mechanism and / or through direct involvement in the management of State-Owned Enterprises or State-Owned Legal Entities as the institutional instrument of the state utilizing its control over the resources to be used for the greatest possible prosperity people. The state's oversight function (toezichthoudensdaad) is undertaken by the Government to supervise and control so that the exercise of control over an important production branch and / or that affect the livelihood of the people is really carried out for the greatest prosperity of all the people. ${ }^{16}$

From an economic point of view. The tendency of business actors to seek

\footnotetext{
16 Jimmly Asshiddiqie. (2005). (2008). (2010). Konstitusi Dan Konstitusionalisme Indonesia. Menuju Negara Hukum Yang Demokratis. Konstitusi Ekonomi. Jakarta: Konstitusi Pers. PT Kompas Media Nusantara. pg. 406
}

monopolistic superiority can be understood when associated with the purpose of establishing a business that is seeking maximum profit, but it should be realized that monopoly acts often endanger the economy. The Government in principle has a great role both in order to create market competition if desired and limit the behavior of monolpolistik that occur because at risk of harm both for the community as consumers and business actors. A good government should always try to correct market failures, for example by preventing monopoly for the sake of efficiency. The government through BUMN can do the monopoly but what is wanted is a social justice monopoly in which people can feel the benefits of the monopoly.

\section{The Role Of Government In Social Justice Monopoly}

To know more about the role of government can be studied in the description below: ${ }^{17}$

a. Efficiency

One major aberration of perfect competition is imperfect competition or monopoly elements. The result of monopoly power is the ability of a giant company to

\footnotetext{
${ }^{17}$ Mc Eachern. William A. (2000). A Contemporary Introduction. Singapore: Thomson Learning Asia. pg. 294
} 
influence prices on the economy as a whole. Monopoly power tends to create a price that is too high, far exceeding the cost of production which in turn leads to a decrease in the level of consumer spending (demand) in the standard limits of excessive price patterns and low output levels is an inefficiency disease that always arises as a result of power monopoly. Governments of various countries are taking steps to overcome monopoly power through direct intervention, price control, and profit of monopolists. The steps taken by the government to overcome the monopoly are done through the actions of various policies. According to Mc. Eachem there are three types of government policy to change or control corporate behavior that is socioregulation $\mathrm{L}$, economic regulation, and antitrust activity. Social regulation is government policy to improve health and safety. Economic regulation, related to price control, output, entry of new companies, and quality of services in industries that are potential for the emergence of monopolists or in the monopolist industry that tends to harm society. Antitrust activity, trying to prohibit the behavior of companies intended to monopolize, or form a cartel, in a market more suited to competition.

b. Equity

Market failures such as the occurrence of monopolies or the difficulties of markets carrying public goods, centered on the weakness of the market's allocative role, but such imperfections can be improved by government intervention, through the policies it makes.

c. Macroeconomic Stability and Growth Besides Increasing efficiency and equity, the government is obliged to perform macroeconomic functions and promote overall economic growth and stability. The main objectives that are the focus of long-term macroeconomic policy are the rate of economic growth and the level of rapid productivity. Economic growth means the same as the growth of the level of output of a country as a whole, while the level of productivity is the ratio of output to the input used to produce it. 
The role of government in overcoming market weakness inefisiensi due to the existence of monopoly practice can be done through intervention to the market by way of policy making in the form of regulation or anti-monopoly law.

Associated with the role of government to make policies through the regulations it makes, according to $\mathrm{Mc}$. Eachem, there are two views on why the government should regulate the market. The first view states that regulation is for the benefit of society. Economic regulation is designed to improve the welfare of society by controlling prices and outputs, ie for markets that would be most efficient if only served by one or more companies. A second view of economic regulation is that economic regulation is not primarily for the special interests of producers. ${ }^{18}$

Based on this view, well-organized producer groups expect profits derived from economic regulation and this group can influence government officials to impose restrictions on entry of new companies into the industry and prevention of competition between existing firms. Individual producers have the possibility of gaining greater amounts of benefits or losses than individual producer consumers are usually also better organized and more

\footnotetext{
${ }^{18}$ Ibid
}

focused than consumers, so manufacturers are usually disguised as to defend the interests of consumers.

This special interest theory remains valid when the objective of endorsing the original rule is for the benefit of the consumer. As time passes, the government that makes the regulation can start to move in favor of the producer's interest, the regulation leads them to arrest (arrest) the government to side with the interests of producers. This theory is known by the theory of arrest of regulation. By George Stigler, a Nobel Prize winner, the theory of arrest of regulation is described as follows: "General rules, regulations are cultivated by industry (producers) and designed and implemented for their benefit. ${ }^{19}$

Thus, when viewed from the theory it can be seen that a regulation made by the government with the aim to the interests of consumers or the general public in the end may be changed used for the benefit of producers. Therefore, in making a regulation to regulate the market is demanded that the regulators are used for the benefit of the public and not just a handful of people.

The role of the state can be divided into three parts: planner, actor / player, and regulator. As a central government planner

${ }^{19}$ Op.Cit, Faisal Basri. pg. 344 
must provide flexibility for local governments to regulate themselves. More sectoral planning should be provided to the technical departments and local government apparatus and fully implemented by the regions. The role of the state as the perpetrator must gradually be reduced in line with the strengthening of the private role and the strengthening of the regulatory framework. This means that the role of the government as a regulator will be increasingly important in order to increase the role of the private sector instead of strengthening the foundation for the creation of just prosperity. Insofar as there is clarity of vision and mission of development in a new framework of defining the role of the state and the existence of a macroeconomic framework that embraces all government measures and policies, agency or agency issues and at which level the management and control of state assets will become easier to consider. Throughout all processes and procedures Pursued transparently and with public accountability, undoubtedly any institution and at whatever level managing state assets will not be a problem.

Starting from the above explanation, it can at least be said that the intensity and direction of government involvement may be categorized by stages. As a country just starting to build, Indonesia could not have picked the slow lane or path that was once traversed by the now more developed countries. At this early stage usually the ability of market mechanism is still limited. The role of government is to reinforce the joints for the upholding of market mechanisms. Usually government intervention takes place in areas where market mechanisms actually guarantee success or even the ability of government intervention to be infiltrated by entrenched interest groups. With sufficient autonomy and government capacity, it will provide more guarantees for the selection of appropriate policy instruments and accompanied by targets and sanctions for those unable to enforce them.

The next stage is to change the direction of interference from the more direct to the more indirect, accompanied by target sharpening and tightening sanctions. Up to this point it seems that implementation in some East Asian countries is quite successful. The increasingly explosive ulcers of business and political practices in Korea and Japan serve as a lesson for us to realize that there are still other stages to go. In Japan this is already increasingly realized and they begin to improve themselves. In Korea it seems that this stage must be passed by 
accompanied by a political crisis and the melelimpangannya some conglomeration as tumbal. There are many signs that we in Indonesia are self-forgetful, even in some cases experiencing set back, for example in the handling of poverty, the protection of small businesses and privatization of public services. The more tread to the next stage, the elements in the system must be retested, institutional strengthening must be prioritized, the reform of the legal instruments must be serious, and no less important or almost absolute is a political reform that further ensures the upholding of democracy. If we neglect these things, then the results of development will be more focused on the few people as they have been. As a result we are unable to realize just prosperity.

In China, the government runs its role by issuing macroeconomic policies to provide a stable economic environment for the growth of entrepreneurs. In doing so, they are less influenced by independent parliament like in the United States. This may affect the functioning of China's macroeconomy and thus, indirectly, affect the environment of entrepreneurs. ${ }^{20}$

The Chinese government in the economic field does not practice Western-

\footnotetext{
${ }^{20}$ Gregory C Chow. (2010). Memahami Dahsyatnya Ekonomi China. Solo: Tiga Serangkai Pustaka Mandiri. pg. 9
}

Pattimura Law Journal Vol.1 Issue 2, March 2017 | 110 style legal systems even though the Chinese legislature has introduced many of the same rules as Western regulations to facilitate economic activities, especially by foreign investors. These rules are not strictly enforced. To be successful, Chinese entrepreneurs must conduct business in the Chinese way. ${ }^{21}$

Government intervention in the economy does not need to be viewed as taboo. The success of East Asian countries is even characterized by strong government intervention. But on the contrary, much intervention does not guarantee the success of economic development. The amount of government intervention also does not automatically reflect the strong role of the government, especially if mixed with personal interests or the ruling elite. So from the outset it must be clearly distinguished between the interests of the government which legitimately represents the sovereignty of the people with the personal interests of the ruling elite. If at this stage we have lost direction, do not expect government interference will have a greater positive impact than negative impact. Interference must be accompanied by government autonomy in formulating the established goals and applying them.

\footnotetext{
${ }^{21}$ Ibid. pg. 11
} 
This autonomy is also a requirement, so it does not necessarily guarantee success because in turn it depends on the government's ability to apply autonomy itself. From the various analyzes that have been conducted by specialists in the economic field, it is generally assumed that the involvement or participation of the State in the economy is due to the failure of market mechanisms to overcome some economic problems, especially those related to macroeconomic issues.

The failure of the capitalist economic system to become the basis of market mechanisms to regulate the State's economy creates fierce criticism and criticism and claims to improve the economic system. Even to the extreme of giving rise to a centralized socialist economic system Centralized control in the hands of the State and known by the socialist economic system is also not last long due to the system's inability to overcome various problems that arise, and even worse than the capitalist economic system itself.

The inability of these two economic systems to improve the economy of society has given rise to an economic system that is a combination of both between the two pre-existing economic systems and the name of a mixed economic system. With this mixed economic system the role of the State and the private sector goes parallel. However, this economic system does not guarantee that the problems that arise will be solved completely. It depends on how much consideration has been made between the State's presence and the private sector in the community economy. If the State is stronger or more influential, then this mixed economic system is more likely to lead to an all-country planned economic system or "etatism". Conversely, if the private sector is larger than the State, then what happens is this mixed economic system is more directed to the capitalist system that base its economic activities on market mechanisms.

The hallmark of this mixed economic system is that this economic system does not adhere to the extreme principle of both capitalist and social economic systems. However, this mixed system tries to embrace the principle of equilibrium that is, each of the economic actors both state and swata is running in parallel or parallel. In other words, that in a mixed economic system in addition to giving freedom to the state to move in the economic field, it also provides the freedom for private 
enterprises to jointly with the state to manage the economic field. ${ }^{22}$

In fact, this mixed economic system is similar to the economic system adopted in Indonesia. The difference lies only in the division of economic actors. In a mixed economic system there are only two economic actors namely, state and private parties. While in Pancasila economic system based on GBHN 1998 consists of three economic actors namely, cooperatives, state enterprises and private businesses. The three economic actors are expected to cooperate with the implementation of business partnership principles in order to realize economic democracy by strengthening national business into a healthy national economic power, independent and resilient in order to become a driver of economic development.

The task of the state in the field of economy since the proclamation of 1945 has been formulated clearly in the fourth paragraph of the Preamble of the 1945 Constitution, which is to protect the entire nation of Indonesia and the entire blood of Indonesia and to promote the general welfare, educate the nation and participate

\footnotetext{
22 Aminuddin Ilmar. (2004). Privatisasi BUMN Di Indonesia. Makassar: Hasanuddin University Press. pg. 100
}

in implementing the world order based on eternal peace And social justice.

The role of the state through BUMN becomes so important when it is formulated in a provision as formulated in Article 33 Paragraph (2) of the 1945 Constitution of the State of the Republic of Indonesia, where the production branches which are important for the State and which affect the livelihood of the public must be controlled by Country. Here it indicates the authority of the State to participate in economic activities through the operation of production branches that can be categorized as important for the State and considered vital and strategic for the interest of the State.

This is based on the reasons as formulated in the explanatory section of Article 33 of the 1945 Constitution of the State of the Republic of Indonesia, so that the benefits of the production branches do not fall into the hands of individuals, the State actively takes the role to cultivate it because the production branch is considered important The State and which control the livelihood of the people for the greatest prosperity of the people. ${ }^{23}$

The involvement of the state in economic activities which concerns the interests and controls the livelihood of the

\footnotetext{
${ }^{23}$ Ibid. pg. 17
} 
people derives from the concept of the State's Right to Control and the economy of the state's economy. Therefore, the draft of the Right to Control the State in Article 33 of the 1945 Constitution is based on: (Explanation of the 1945 Constitution of the Republic of Indonesia).

a) Considerations of economic democracy;

b) To avoid the accumulation of production and to fall into the hands of those in power; And

c) To avoid the oppression of the masses by those who are economically and politically very strong.

Thus, it can be concluded that the linkage between state goals and functions with the concept of a welfare state based on the Pancasila economic system through fair market mechanism does not deny state control through state enterprises (SOEs) in the economic field. Similarly, the mastery of some communities through cooperatives and private sector is recognized in the Pancasila economic system.

The Constitution explicitly states that sovereignty is in the hands of the people and is carried out in accordance with Of the Constitution.In the 1945 Constitution of the Republic of Indonesia also states that Indonesia is a State of Law. The principle of the law states rests on the theory of law sovereignty expressed by Krabbe in response to the theory of state sovereignty.This theory states that sovereignty derives from the legal awareness of the community, Where legal awareness is generally accepted. In the theory of sovereignty of the law then the sovereign law so that the state must be subject to the rule of law. ${ }^{24}$

The conception developed by Grotius and Hobbes also connects between the people and the state through a social contract. Social contracts were originally regarded as historical facts, and then developed as postulates of pure reason. The source of political power is the people, and in this context, the role of the state becomes important to protect the interests of society including the unlucky economy. Therefore, the state has a very big role to ensure that natural resources and branches of production are important for the interests of the people, and more concretely addressed, aimed at the livelihood of many people.

Based on the above description, the function and role of the State in relation to economic activity, in particular the market, as noted in the previous section, may include: regulator, protector, entrepreneur

\footnotetext{
24 Wirjono Prodjodikoro. (1981). Asas-Asas Ilmu Negara Dan Politik. Jakarta: Eresco. pg. 47
} 
and umpire. The latter function of the State not only has a role to ensure that law is enforced consistently in the event of a violation of established policies and regulations. The function of this referee must also be able to guarantee the implementation of enforcement because the economic process required predictability based on legal certainty and one of the guarantee of the realization of predictability due to a certainty of law and one of the guarantee of the realization of predictability because of a certainty through clear and firm law enforcement within An association in society. In this context, States can press for preventive policies to be an integral part of enforcement action, especially to eliminate potential misuse of authority or power to prevent monopolies that only benefit a group of people.

In the context of Indonesia, the mandate in the opening of the constitution as mentioned in the preamble of the 1945 Constitution of the Republic of Indonesia has affirmed the obligation to realize public welfare, and on the body of the 1945 Constitution has been formulated clearly that the national economy is organized with certain principles, Namely: togetherness, efficiency fair, sustainable, environmentally friendly, independence and by maintaining the balance of progress and national economic unity. The principle is intended to achieve economic democracy. The whole description has affirmed that the State was formed to bring about welfare so that it can be called that Indonesia is a welfare state.Indonesia is a welfare state and also a state law.In a welfare state, the State is required and still placed to be responsible in controlling the national economy in order Achieve the ideals of social justice.

\section{CONCLUSION}

As mentioned earlier, the State intervenes in the economic field through a stateowned enterprise. The discourse of State interference is the discourse of the actualization of the work of SOEs which thereby means the State in the context of interference in the economic field equal to the SOEs.

State-Owned Enterprises is formed with the aim of contributing to the development of the national economy in general and the state's revenue in particular; The pursuit of profit; To hold general benefit in the form of providing goods and / or services of high quality and adequate for the fulfillment of the livelihood of the public; Pioneering business activities that have not yet been 
implemented by the private sector and cooperatives and actively providing guidance and assistance to weak economic entrepreneurs, cooperatives, and communities.

SOE management has a lot of political content. At the beginning of the SOE growth period, political and characterized actions are demonstrated to ensure the protection of the State's interests, for example by nationalization policies and the formation of vital and strategic corporations.

In subsequent periods at the level of execution or management, the nature and political content of power exercises are subject to change and have a tendency to turn into a vested interest charge of a particular individual or group. At this point comes the facts and potential abuse of authority inherent in certain public positions that are shown for their own and / or group's interests and often use excuses for the benefit of government and society.

There are many bodies "authorized" to build and supervise SOE, is between Other: Board of Commissioners, Inspectorate and Directorate General at Technical Department, Finance and Development Supervisory Board, Kopkamtib, Directorate at Finance Department, DPR, Local Government and others. The authority possessed by many parties, it creates problems because each of them can insist on the will of which is not based on the interests of coaching and partly it is not based on the interests of coaching and partly it is not based on the interests of coaching and supervision. All of which can also lead to potential abuse of authority.

Unconsolidated authority causes SOEs to be unable to exercise their maximum authority due to the various interests that hide behind the authority of public oversight and "interests". Impacts that arise, state-owned companies in the form of persero to be unable to adapt quickly as a corporation, in particular, in answering the needs and challenges of the market and the development of competition that occurred in the business world.

Issues related to recruitment mechanism and nomination of BUMN corporate leaders are not clear. The absence of a measure to determine the criteria for success of leaders and corporate bodies, bureaucratic organs and bureaucratic structures that are not conducive to dealing with markets, and limited professional level of corporate officers and staffs are the main factors that cause SOEs not maximally to achieve their 
formation goals and are unable to compete in Regional and global competition.

In the situation of performance and the ability of SOEs to be limited in managing corporations properly and properly, and the existence of "intervention" of State organizers that are not fully aimed at improving the capacity and competence of SOEs and there is even tendency to use authority based on their own interests and / or groups, Such conditions create potential abuse of authority. If such a situation occurs massively in most SOEs, then the purpose and objectives of the establishment of SOEs is difficult to achieve which of course affects the implementation of a social justice monopoly.

\section{BIBLIOGRAPHY}

Aminuddin Ilmar. (2004). Privatisasi BUMN di Indonesia. Makassar: Hasanuddin University Press.

Budi Sujiono, (2004), Ekonomi Berkeadilan Sosial. Jakarta: PT Golden Terayon Press.

Faisal Basri. (2002). Perekonomian Indonesia Tantangan dan Harapan bagi Kebangkitan Indonesia. Jakarta: Erlangga. (2009). Lanskap Ekonomi Indonesia. Jakarta: Kencana.

Edwin Mansfield (ed).(1994). Monopoly Power and Economic Performance An Introduction To A Current Issue of Public Policy. New York: W. W. Norton.
Friedman,W. (1990). The State and Filosophi of Law (Teori dan Filsafat Hukum). Translate by Muhammad Arifin. Jakarta: CV. Rajawali.

George Susan.(2002).Republik Pasar Bebas : Menjual Kekuasaan Negara, Demokrasi dan Civil Society kepada Kapitalisme.Jakarta: Global, PT Bina Pariwara.

Gregory C Chow. (2010). Memahami Dahsyatnya Ekonomi China. Solo: Tiga Serangkai Pustaka Mandiri.

John Rawls. (2006). A Theorie of Justice; Teori Keadilan, dasar-Dasar Filsafat Politik untuk Mewujudkan Kesejahteraan Sosial dalam Negara.Yogyakarta: Pustaka Pelajar.

Jimmly Asshiddiqie. (2005. 2008.2010). Konstitusi dan Konstitusionalisme Indonesia. Menuju Negara Hukum yang Demokratis.Konstitusi Ekonomi.Jakarta:Konstitusi Pers. PT Kompas Media Nusantara.

(2008). Menuju Negara Hukum yang Demokratis. Jakarta: PT Bhuana Ilmu Populer.

Mc Eachern. William A. (2000). A Contemporary Introduction. Singapore: Thomson Learning Asia.

Munrokhim Misanam Priyonggo Suseno M bhekti Hendrieanto. (2007). Ekonomi Islam. Jakarta: Rajagrafindo Persada.

Roger A Freeman. (1975). The Growth of American Government. A Morphologoy of Welfare State. Stanford.

Sri Redjeki Hartono. (2007). Hukum Ekonomi Indonesia. Malang:PT Bayumedia.

Wirjiono Prodjodikoro. (1981). Asas-asas Ilmu Negara dan Politik.Jakarta: Eresco. 


\section{Legislation}

Undang-Undang Dasar Negara Republik Indonesia 1945. Amandemen Tahun 1999 Dan Amandemen Tahun 2000.

Ketetapan MPR Nomor IV/MPR/1999 tentang Garis-Garis Besar Haluan Negara.

Undang-Undang Republik Indonesia Nomor 5 Tahun 1999 Tentang Larangan Praktek Monopoli dan Persaingan Usaha Tidak Sehat.

Undang-Undang Republik Indonesia Nomor 25 Tahun 2000 Tentang Program Pembangunan Nasional (Propenas) Tahun 2000-2004.

Restrictive Trade Practices Act 1976.

Uruguay roud. Final Act. Marakesh 15 April 1994.

Economic Planning Board Republic of Korea. 